\title{
Assessing the Racial and Ethnic Disparities in Breast Cancer Mortality in the United States
}

\author{
Clement G. Yedjou ${ }^{1, *}$, Paul B. Tchounwou ${ }^{1}$, Marinelle Payton ${ }^{2}$, Lucio Miele ${ }^{3}$, \\ Duber D. Fonseca ${ }^{1}$, Leroy Lowe ${ }^{4}$ and Richard A. Alo ${ }^{5}$
}

1 Natural Chemotherapeutics Research Laboratory, Research Centers in Minority Institutio (RCMI)-Center for Environmental Health, College of Science, Engineering and Technology, Jackson State University, 1400 Lynch Street, Box 18750, Jackson, MS 39217, USA; paul.b.tchounwou@jsums.edu (P.B.T.); gomezfonseca@gmail.com (D.D.F.)

2 Center of Excellence in Minority Health and Health Disparities, School of Public Health, Jackson State University, Jackson Medical Mall-Thad Cochran Center, 350 West Woodrow Wilson Avenue, Jackson, MS 39213, USA; marinelle.payton@jsums.edu

3 Department of Genetics, LSU Health Sciences Center, School of Medicine, 533 Bolivar Street, Room 657, New Orleans, LA 70112, USA; lmiele@lsuhsc.edu

4 Lancaster Environment Centre, Lancaster University, Bailrigg, Lancaster LA1 4YW, UK; leroy.lowe@gettingtoknowcancer.org

5 Department of Civil and Environmental Engineering, College of Science, Engineering and Technology, Jackson State University, 1400 Lynch Street, Box 18750, Jackson, MS 39217, USA; richard.a.alo@jsums.edu

* Correspondence: clement.yedjou@jsums.edu; Tel.: +1-601-979-0215; Fax: +1-601-979-5853

Academic Editor: Jayajit Chakraborty

Received: 28 December 2016; Accepted: 26 April 2017; Published: 5 May 2017

\begin{abstract}
Breast cancer is the second leading cause of cancer related deaths among women aged 40-55 in the United States and currently affects more than one in ten women worldwide. It is also one of the most diagnosed cancers in women both in wealthy and poor countries. Fortunately, the mortality rate from breast cancer has decreased in recent years due to increased emphasis on early detection and more effective treatments in White population. Although the mortality rates have declined in some ethnic populations, the overall cancer incidence among African American and Hispanic populations has continued to grow. The goal of the present review article was to highlight similarities and differences in breast cancer morbidity and mortality rates primarily among African American women compared to White women in the United States. To reach our goal, we conducted a search of articles in journals with a primary focus on minority health, and authors who had published articles on racial/ethnic disparity related to breast cancer patients. A systematic search of original research was conducted using MEDLINE, PUBMED and Google Scholar databases. We found that racial/ethnic disparities in breast cancer may be attributed to a large number of clinical and non-clinical risk factors including lack of medical coverage, barriers to early detection and screening, more advanced stage of disease at diagnosis among minorities, and unequal access to improvements in cancer treatment. Many African American women have frequent unknown or unstaged breast cancers than White women. These risk factors may explain the differences in breast cancer treatment and survival rate between African American women and White women. New strategies and approaches are needed to promote breast cancer prevention, improve survival rate, reduce breast cancer mortality, and ultimately improve the health outcomes of racial/ethnic minorities.
\end{abstract}

Keywords: breast cancer; racial disparity; health disparity; African American 


\section{Introduction}

Breast cancer is the second leading cause of cancer related deaths of women aged 40-55 in the United States and currently affects more than one in ten women worldwide [1]. In the United States African American and Hispanic women have a lower incidence of breast cancer compared to White women. Although African American and Hispanic women have a lower incidence of breast cancer, they have a higher mortality rate. A scientific data collected between 2000 and 2010 revealed that cancer incidence is higher among Black men compared to White men and higher among White women compared to Black women [2]. However, cancer mortality over the same time period was higher for both Black men and women compared to White men and women [3]. Scientific studies have identified possible differences in biological properties and especially in the plasma levels of growth factors and hormones [4], reproductive factors [5,6], susceptibility loci [7,8], and primary tumor characteristics, including the presence and expression of steroid and growth factor receptors [6,9-11], cell cycle proteins [12-15], tumor suppressor genes [15,16], and chromosomal abnormalities [17], between African American women and White women. These possible difference in biological properties between African American women and White women have the potential to influence breast cancer screening and treatment outcomes between the two ethnic groups. Since early 1990s, several strategies including early detection and diagnosis, reduction of tobacco smoking, widespread of cancer breast screening, and improvement of breast cancer therapies have been developed to improve the health of patients with breast cancer $[18,19]$. Although there has been an improvement in early detection, diagnosis, and screening, many Black women are less likely to get better treatment compared with White women $[20,21]$. Therefore, new strategies and approaches are needed to promote breast cancer prevention, improve survival rate, reduce breast cancer mortality, and ultimately improve the health outcomes of racial/ethnic minorities.

\section{Methodology}

A review of relevant scientific publications addressing breast cancer disparity and mortality rate primarily among African American women compared to White women in the United State was done using Google Scholar (https://scholar.google.com/). Protocols and initiatives by government programs and other non-governmental agencies were extensively studied, and archives of media coverage on breast cancer. Additionally MEDLINE, and PUBMED (https://www.ncbi.nlm.nih. gov/pubmed) searches were conducted. We mostly examined populations of White women and African American women in the United States. An attempt was made to include all relevant references examining the nature and magnitude as well as the major risk factors associated with breast cancer disparity.

\section{Results and Discussion}

The result and discussion sessions of this review article provide an overview of breast cancer, racial/ethnic disparities in breast cancer, breast cancer incidence and mortality rate linked to hereditary, major risk factors of breast cancer among minority population, breast cancer treatment and health disparity.

\subsection{Overview of Breast Cancer}

Breast cancer is a malignant tumor that starts in the cells of the breast. It is found mostly in women, but men can get breast cancer too. It is the most diagnosed cancer in women both in the developing and wealthy or developed countries. Worldwide, breast cancer survival rates vary greatly with approximately $80 \%$ in North America, Japan and Sweden to about $60 \%$ in middle-income countries and below $40 \%$ in poor countries [22]. African American women are more likely to be diagnosed with breast cancer at a younger age than White women [23]. For example, the median age at diagnosis for African American women is 59, compared to 63 for White women [23]. However, breast cancer 
incidence is lower among African-American women than among White women [23]. Although the incidence of breast cancer is slightly low among African American women, the mortality rate of breast cancer is significantly higher in this ethnic group compared to White women $[24,25]$.

\subsection{Racial/Ethnic Disparities in Breast Cancer}

Racial/ethnicity disparities in breast cancer mortality rates are not completely understood, but the common risk factors include socioeconomic status, differential access to health care, and disease related molecular mechanistic differences [26]. There are a disproportionate number of cancer deaths occurring among African Americans with approximately 33\% higher risk of dying of cancer than Whites. Recent report demonstrates that African American with breast cancer have a poorer prognosis compared to non-Hispanic Whites when diagnosed at a similar age and stage [27]. Overall, the mortality rate of breast cancer is still higher among Black, Hispanic, and Native American women than among White women [28,29]. Between 2002 and 2008, the relative 5 year survival rate for breast cancers incidence was 78\% among Black women and 90\% among White women [30]. The gap in breast cancer mortality rate between Black women and White women continues to increase. Between 2000 and 2010, the breast cancer mortality disparity ratio increased from $30.3 \%$ to $41.8 \%$ among African American women. At the advanced stage, 5\% of breast cancers are detected among White women compared to $8 \%$ of breast cancers among Black women [30]. Number of breast cancer incidence and mortality per 100,000 women is represented in Figure 1 according to a 2015 report.

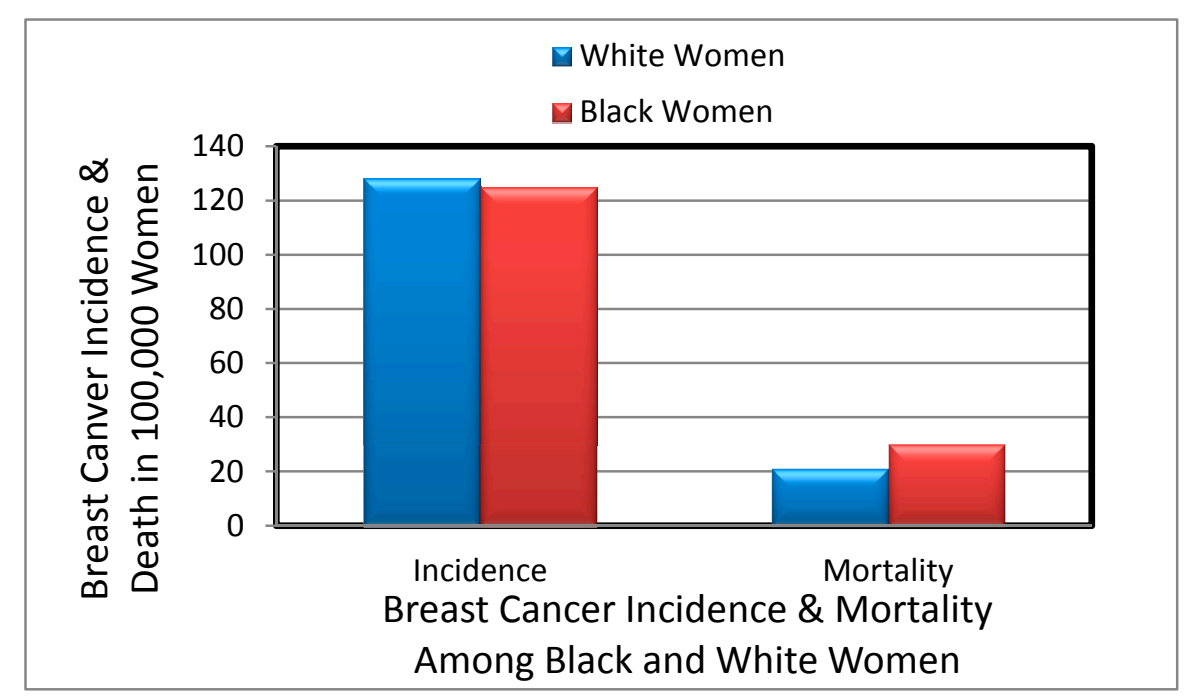

Figure 1. Number of breast cancer incidence and mortality among Black women and White women.

A recent collaborative epidemiological study reported that Black males have high incidence rates for all cancers combined (12\% higher) and for the most common cancers, including cancers of the prostate, lung, colorectum, kidney, and pancreas. In contrast, Black females have a $6 \%$ lower overall incidence rate for all cancers combined and for many cancers, including lung, breast (only 3\% lower), and uterine cancers [31]. Cancer incidence rates between Non-Hispanic (NH) Blacks and Whites in the United States between 2008 and 2012 are reported in Table 1 below. 
Table 1. Comparison of Cancer Incidence Rates between Non-Hispanic (NH) Blacks and Whites, United States, 2008-2012 [31].

\begin{tabular}{|c|c|c|c|c|c|c|c|c|c|}
\hline \multicolumn{5}{|c|}{ Male } & \multicolumn{5}{|c|}{ Female } \\
\hline Cancer & $\begin{array}{c}\text { NH Black } \\
\text { Rate }^{a}\end{array}$ & $\begin{array}{l}\text { NH White } \\
\text { Rate }^{\text {a }}\end{array}$ & $\begin{array}{c}\text { Absolute } \\
\text { Difference }\end{array}$ & $\begin{array}{c}\text { Rate } \\
\text { Ratio }^{c}\end{array}$ & Cancer & $\begin{array}{c}\text { NH Black } \\
\text { Rate }^{a}\end{array}$ & $\begin{array}{l}\text { NH White } \\
\text { Rate }^{a}\end{array}$ & $\begin{array}{c}\text { Absolute } \\
\text { Difference }^{b}\end{array}$ & $\begin{array}{l}\text { Rate } \\
\text { Ratio }^{c}\end{array}$ \\
\hline Kaposi sarcoma & 1.7 & 0.5 & 1.2 & $3.57^{\mathrm{d}}$ & Kaposi sarcoma & 0.2 & $<0.1$ & 0.1 & $3.96^{\mathrm{d}}$ \\
\hline Myeloma & 14.8 & 7.0 & 7.8 & $2.11^{\mathrm{d}}$ & Myeloma & 11.1 & 4.3 & 6.8 & $2.58^{\mathrm{d}}$ \\
\hline Stomach & 15.1 & 7.8 & 7.3 & $1.93^{\mathrm{d}}$ & Stomach & 8.0 & 3.5 & 4.5 & $2.30^{\mathrm{d}}$ \\
\hline Liver \& IHB & 16.5 & 9.3 & 7.2 & $1.77^{\mathrm{d}}$ & Liver \& IHB & 4.8 & 3.2 & 1.6 & $1.52^{\mathrm{d}}$ \\
\hline Prostate & 208.7 & 123.0 & 85.7 & $1.70^{\mathrm{d}}$ & Uterine cervix & 10.0 & 7.1 & 2.9 & $1.41^{\mathrm{d}}$ \\
\hline Larynx & 9.3 & 6.3 & 3.0 & $1.48^{\mathrm{d}}$ & Pancreas & 14.4 & 10.6 & 3.8 & $1.36^{\mathrm{d}}$ \\
\hline Breast & 2.0 & 1.4 & 0.6 & $1.45^{\mathrm{d}}$ & Esophagus & 2.5 & 1.8 & 0.7 & $1.34^{\mathrm{d}}$ \\
\hline Colon \& rectum & 60.3 & 47.4 & 12.9 & $1.27^{\mathrm{d}}$ & Colon \& rectum & 44.1 & 36.2 & 7.9 & $1.22^{\mathrm{d}}$ \\
\hline Pancreas & 17.2 & 14.0 & 3.2 & $1.23^{\mathrm{d}}$ & Kidney \& renal pelvis & 13.0 & 11.3 & 1.7 & $1.15^{\mathrm{d}}$ \\
\hline Lung \& bronchus & 93.4 & 79.3 & 14.1 & $1.18^{\mathrm{d}}$ & Breast & 124.3 & 128.1 & -3.8 & $0.97^{\mathrm{d}}$ \\
\hline Kidney \& renal pelvis & 24.2 & 21.8 & 2.4 & $1.11^{\mathrm{d}}$ & Uterine corpus & 23.0 & 25.5 & -2.5 & $0.90^{\mathrm{d}}$ \\
\hline Hodgkin lymphoma & 3.2 & 3.4 & -0.2 & $0.95^{\mathrm{d}}$ & Hodgkin lymphoma & 2.4 & 2.7 & -0.3 & $0.88^{\mathrm{d}}$ \\
\hline Esophagus & 8.0 & 8.8 & -0.8 & $0.90^{\mathrm{d}}$ & Lung \& bronchus & 51.4 & 58.7 & -7.3 & $0.87^{\mathrm{d}}$ \\
\hline Oral cavity \& pharynx & 15.3 & 18.1 & -2.8 & $0.84^{\mathrm{d}}$ & Leukemia & 8.6 & 10.7 & -2.1 & $0.80^{\mathrm{d}}$ \\
\hline Leukemia & 13.2 & 17.7 & -4.5 & $0.75^{\mathrm{d}}$ & Oral cavity \& pharynx & 5.2 & 6.7 & -1.5 & $0.78^{\mathrm{d}}$ \\
\hline Non-Hodgkin lymphoma & 17.2 & 24.1 & -6.9 & $0.71^{\mathrm{d}}$ & Ovary & 9.6 & 12.4 & -2.8 & $0.77^{\mathrm{d}}$ \\
\hline Brain \& ONS & 4.9 & 8.8 & -3.9 & $0.56^{\mathrm{d}}$ & Non-Hodgkin lymphoma & 12.0 & 16.6 & -4.6 & $0.72^{\mathrm{d}}$ \\
\hline Urinary bladder & 19.8 & 40.2 & -20.4 & $0.49^{\mathrm{d}}$ & Urinary bladder & 6.7 & 9.9 & -3.2 & $0.68^{\mathrm{d}}$ \\
\hline Thyroid & 3.7 & 7.7 & -4.0 & $0.48^{\mathrm{d}}$ & Thyroid & 12.9 & 21.9 & -9.0 & $0.59^{\mathrm{d}}$ \\
\hline Testis & 1.4 & 6.8 & -5.4 & $0.21^{\mathrm{d}}$ & Brain \& ONS & 3.6 & 6.3 & -2.7 & $0.58^{\mathrm{d}}$ \\
\hline Melanoma of the skin & 1.1 & 31.3 & -30.2 & $0.04^{\mathrm{d}}$ & Melanoma of the skin & 1.0 & 20.6 & -19.6 & $0.05^{\mathrm{d}}$ \\
\hline All sites & 592.3 & 528.9 & 63.4 & $1.12^{\mathrm{d}}$ & All sites & 408.1 & 436.2 & -28.1 & $0.94^{\mathrm{d}}$ \\
\hline
\end{tabular}

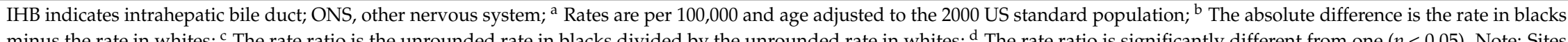
are listed in descending order by rate ratio; Source: North American Association of Central Cancer Registries [31]. 


\subsection{Majors Risk Factors in Breast Cancer Affecting Minority Populations}

The specific causes of breast cancer still remain unknown, but we do know that a woman's chances of developing breast cancer are related to a wide range of risk factors including woman's age, genetic factors, family history, personal health history, and diet. Lifestyle and environmental factors are also known to be responsible for a considerable portion of cancer incidence worldwide [32].

\subsubsection{Age and Sex Risk Factors in Breast Cancer}

Age and sex are the most important risk factors to be considered in breast cancer incidence rates. Breast cancer incidence rates are higher among Blacks than Whites for women under age 45 . The median age of diagnosis is 58 years for Black women compared with 62 years for White women [33]. The overall lifetime risk is 1 in 9 Black women expected to be diagnosed with breast cancer compared with 1 in 8 White women. Approximately $1 \%$ of all cases of breast cancer occur in men. At the age of up to 30 the risk of an individual developing breast cancer is 1 in 1900, but rises to 1 in 15 by the age of 70 .

\subsubsection{Genetic Risk Factors in Breast Cancer}

Family history has long been known to be a risk factor for breast cancer. For example, if members of a patient's family have had particular types of cancer, the patient will have an increased risk of developing breast cancer $[34,35]$.

$B R C A 1$ and $B R C A 2$ are human genes that produce tumor suppressor proteins. These proteins help repair damaged DNA and, therefore, play a role in ensuring the stability of the cell's genetic material. When either of these genes is mutated, altered, or does not function correctly, DNA damage may not be repaired properly. As a result, cells are more likely to develop additional genetic alterations that can lead to cancer development. The mutations of these two genes (BRCA1 and BRCA2) are thought to account for between $5 \%$ and $10 \%$ of all breast cancer cases [36] and approximately $15 \%$ for ovarian cancers [37]. Female women with BRCA1 gene have an increased risk of developing breast cancer at an early age [38].

A harmful BRCA1 or BRCA2 mutation can be inherited from a person's mother or father. Each child of a parent who carries a mutation in one of these genes has a $50 \%$ chance to inherit the mutation. Specific inherited mutations in $B R C A 1$ and $B R C A 2$ increase the risk of female breast and ovarian cancers, and they have been associated with increased risks in many cancer types. Together, $B R C A 1$ and BRCA2 mutations account for about 20 to $25 \%$ of hereditary breast cancers [39] and about 5 to $10 \%$ of all breast cancers [36]. In human breast cancer, genetic deletions have been demonstrated to be one of the major genetic abnormalities. Loss of heterozygosity in breast cancer has been documented at several chromosomal locations, including 1p, 1q, 2p, 3p, 6q, 7q, 8q, 9q, 11p, 11q, 13q, 15q, 16q, 17p, $17 q, 18 p, 18 q$ and 22q [40]. The Loss of heterozygosity in few of chromosomal regions or locations have been shown to include a known 6 tumor suppressor gene implicated in breast cancer, such as p53 at chromosome 17q13 [41,42], BRCA-1 at 17q21 [43] and BRCA-2 at 13q12-13 [44]. The differences in the genetics and biology of breast cancer incidence among Black women compared with White women are well documented in the literature. A breast cancer research that has evaluated 4885 White patients, 1,016 Black patients, and 777 Hispanic patients reported a significant differences in 5-year survival rates [45]. Finding from this research reported a five-year survival rate of $75 \pm 1 \%$ for white patients, $70 \pm 2 \%$ for Hispanic patients, and $65 \pm 2 \%$ for black patients [45]. In addition to mutations in BRCA1 and BRCA2 genes, mutations of ATM, CDH1, CHEK2, PALB2, PTEN, STK11, TP53 (p53) genes can also increase the risk of breast cancer [46]. Possible genes mutations associated with breast cancer development are reported in Figure 2.

Despite most of the breast cancers are not of hereditary origin, lifestyle and environmental factors such as diet, obesity, smoking, alcohol consumption, infection diseases, and radiation have a profound influence on cancer development [47]. Although the hereditary factors cannot be modified, lifestyle 
and environmental factors that affect the incidence and mortality rate of breast cancer are modifiable and can be prevented.

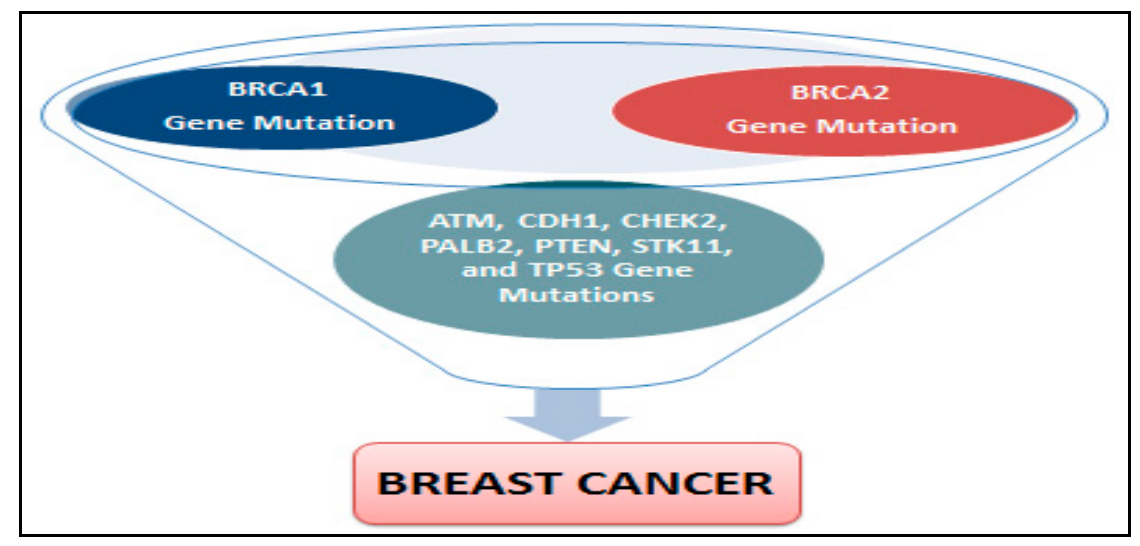

Figure 2. Possible genes mutations associated with breast cancer development.

\subsubsection{Lack of Physical Activity Risk Factors in Breast Cancer}

Breast cancer has been one of the most extensively studied cancers in relation to physical activity, with more than 60 studies that have reported this association published in Asia, and Australia, Europe, and United State. Many studies in the United States and around the world have consistently found that physically active women have a lower risk of developing breast cancer compared to inactive women. However, the percentage of risk reduction achieved through physical exercise varies between $20 \%$ and $80 \%$ with the greatest risk reduction seen among those who are most active [48,49]. Similarly, a review of 73 observational studies indicated that moderate to vigorous physical activity reduces breast cancer risk by an average of $25 \%$ in pre- and post-menopausal women compared with inactive women [50]. Although it is possible that women who are physically active experience a reduction in risk of breast cancer, the biological mechanisms of action explaining this association are still largely unknown. A 2006 report indicated that physical activity may prevent against breast cancer and tumor development by lowering hormone levels, reducing levels of insulin and insulin-like growth factor I, improving the immune response; and assisting with weight maintenance to avoid a high body mass and excess body fat [48].

\subsubsection{Poor Diet, Obesity, and alcohol Consumption Risk Factors in Breast Cancer}

A systematic review conducted by Albuquerque and his collaborators found that Mediterranean dietary pattern and diets rich of vegetables, fruit, fish, and soy are associated with a decreased risk of breast cancer [51]. Other studies reported that intakes of dietary fiber, fruit, and vegetables significantly reduce breast cancer risk factors [52-55]. However, poor diet and lack of physical exercise may lead to weight gain which plays a role in the development of breast cancer and survival rate of African American women [56].

A recent report has linked obesity to an increased risk of developing breast cancer [57]. Other report indicated that obesity increases the risk of breast cancer in postmenopausal women by approximately $30 \%$ for women with a Body Mass Index (BMI) of greater than $31 \mathrm{~kg} / \mathrm{m}^{2}$. A BMI of greater than $35 \mathrm{~kg} / \mathrm{m}^{2}$ is associated with a doubling of the risk of breast cancer [58]. How diet contributes to cancer remains likely unknown. A 2000 report indicated that diet may contribute to approximately $50 \%$ of all to breast cancers [59]. In addition to breast cancer, high percentages of other cancers that have been linked to diet factors are represented in Figure 3. 


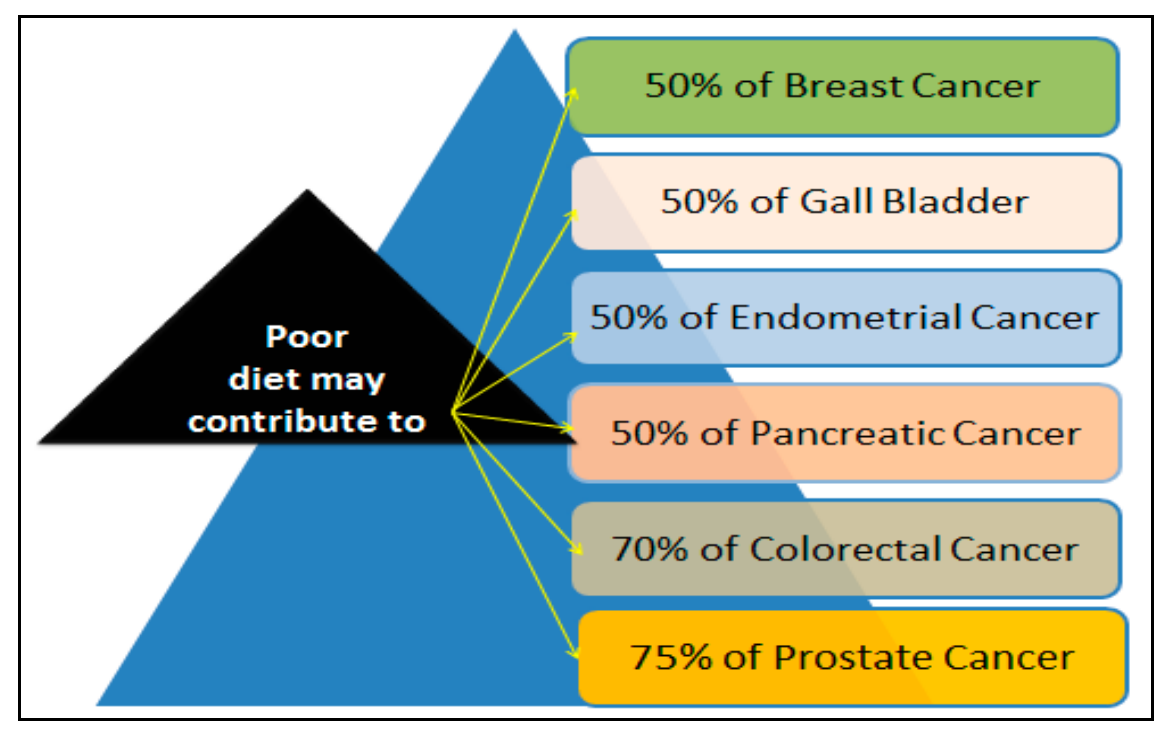

Figure 3. High percentages of breast cancer and other cancer deaths associated with poor diet.

Alcohol consumption plays an important role in the development of breast cancer. For example, previous studies have suggested that increased breast cancer risk is associated with both the amount and the duration of alcohol consumption [60,61]. Nagata et al. (1997) [62] provided evidence that alcohol consumption may increase serum levels of estradiol, suggesting that alcohol consumption is indirectly associated with the development of breast cancer by increasing the exposure to estrogen. A collaborative re-analysis of individual data from 53 epidemiological studies, including 58,515 women with breast cancer and 95,067 women without breast cancer has evaluated the association between alcohol consumption and breast cancer incidence [63]. They found a linear increase in breast cancer risk with increasing alcohol consumption. They concluded that the relative risk of breast cancer is 1.32 for women drinking between $35 \mathrm{~g}$ and $44 \mathrm{~g}$ of alcohol per day and 1.46 for women drinking $45 \mathrm{or}$ more grams of alcohol per day. They also found a $7.1 \%$ increase in the relative risk of breast cancer for 8 each additional $10 \mathrm{~g}$ of alcohol consumed per day. The summary from these epidemiological studies estimated that $4 \%$ of all breast cancers are attributable to alcohol consumption [63]. The International Agency for Research on Cancer estimates that approximately one fourth to one third of cancer cases are associated with elevated body weight and inadequate physical activity [64]. Previous scientific reports indicated that African Americans are more overweight, obese, and have higher BMI and waist-to-hip ratios compared to Caucasians [65,66]. It is estimated that more than $50 \%$ of African American women aged 40 years or older are obese and more than $80 \%$ are overweight [67]. The lack of physical exercise may explain why African American women have higher rates of obesity, a major risk factor of breast cancer in Black women compared to other ethnic groups [68].

\subsection{Breast Cancer Prevention, Treatment and Health Disparity}

A recent report suggests that half of breast cancer cases may be prevented if chemoprevention is applied in appropriate at-risk populations and the major modifiable risk factors such as achieving and maintaining a healthy weight, regular physical activity, and minimal alcohol intake are instituted [69]. However, scientific evidence revealed that racial/ethnic disparities in breast cancer are attributed to risk factors such as lack of medical coverage, barriers to early detection and screening, more advanced stage of disease at diagnosis among minorities, and unequal access to improvements in cancer treatment. These factors may explain the differences in survival rate between African American and White women [70-72]. There is also scientific evidences suggesting that the prevalence of estrogen receptor-positive breast tumors may be lower in African Americans and Hispanics than in Whites [46,73], which might account for racial/ethnic differences in the use of tamoxifen. Further 
evidence suggests that, because of the increased risk of stroke, pulmonary embolism, and deep vein thrombosis associated with tamoxifen, African Americans, who already have a higher prevalence of risk factors for these conditions, may receive less overall benefit from tamoxifen [27].

National Cancer Institute (NCI)-supported research indicated that aggressive breast tumors are more common in younger African American and Hispanic women living in low socioeconomic status (SES) areas. This more aggressive form of breast cancer is less responsive to standard cancer treatments and is associated with lower survival rate [72]. A 2000 Survey of eight New York State hospitals found that physicians have more negative perceptions of African Americans and persons of low or middle SES than of Whites and persons of high socioeconomic status [74]. This finding and lack of information on how physician attitudes toward patients affect their care need further research, particularly with regard to how such negative perceptions might contribute to racial/ethnic disparities in cancer treatment.

A 2014 study by the Carolina Breast Cancer found racial differences in physical activity among breast cancer survivors revealed that African American, compared to Caucasian women, are significantly less likely to meet national physical activity guidelines after diagnosis [75]. The lack or limited physical exercises have some implications for breast cancer care. The Sisters Network Inc. suggests that only $47 \%$ of African American Breast Cancer survivors may be meeting these physical activity guidelines. Another study by the Northeast Ohio Breast Cancer survivors found a gradual decline in physical activity levels after high school completion in African American compared to White women and revealed that only $12.3 \%$ of African American breast cancer survivors were meeting exercise guidelines [76]. A proposed breast cancer care model recommended that breast cancer patients should be educated about the importance of physical exercise at the point of breast cancer diagnosis, and provide them with the necessary support to stay active during the stage of breast cancer diagnosis-treatment continuum and beyond [77].

\subsection{Mechanisms of Apoptosis Resistance in Breast Cancer Treatment}

Apoptosis resistance in breast cancer is the major cause for female cancer mortality in the wealthy countries. Understanding apoptosis in disease conditions is very important as it not only gives insights into the pathogenesis of a disease, but may also give clues on how the disease can be treated. In cancer, there is a loss of balance between cell division and cell death and cells that should have died, but did not receive the signals to do so. The problem can arise in any one step along the way of apoptosis. Several tumor suppresser genes have been identified, and mutations in these genes have been associated with a variety of neoplastic conditions. One example is the downregulation of p53, a tumor suppressor gene, which results in reduced apoptosis and enhanced tumor growth and development [78]. Inactivation of p53 has been linked to many human cancers regardless of the mechanism [79,80]. It is an important regulator of cell cycle progression and DNA damage repair. Many studies have reported that p53 is mutated in most African American breast cancer [12,13,46], but other studies have not [81]. The tumor suppressor gene RASSF1A modulates multiple apoptotic and cell cycle checkpoint pathways, restricting exit from G1 [82]. RASSF1A in breast cancer among women aged $<50$ years was found to be methylated in $76 \%$ of cases of African American women versus $29 \%$ of cases of Caucasian women $(p<0.0001)$ [15]. RAR $\beta$ (trend, $p=0.01)$ and HIN-1 $(p<0.0001)$ are more often methylated in the tumors of African American women [15]. RAR $\beta$ causes cell cycle arrest, growth inhibition and induction of apoptosis, and HIN-1 in cycle reentry [83]. Scientific data indicate that breast cancer in African American women is characterized by enhanced expression of cyclin E $[12,13,84]$, which regulates entry into S-phase. High levels of cyclin E expression are associated with larger, estrogen receptor (ER)-negative tumors, consistent with tumors in African American women [85].

Despite an increased emphasis on early detection/screening, more effective treatments, and the greater understanding of the molecular pathways underlying breast cancer biology, a major fraction of patients have recurrent disease that becomes refractory to most of the available therapies [86]. Current treatment depends on the type and the stage which can be local or systemic. Local treatment 
involves the treatment without affecting the rest of the body. It includes: (1) surgery which may be breast-conserving surgery whereby part of the breast is removed and mastectomy whereby the entire breast is removed; (2) radiation therapy which involves a high energy rays or particles to destroy the cancer cells. Systemic treatment includes the use of cytotoxic, hormonal, and immunotherapy which is usually used in the adjuvant, neoadjuvant, and metastatic settings. While these systemic agents are active and effective in the majority of breast cancers, after a variable period of time, progression occurs in some cases. Resistance to therapeutic drugs in breast cancer is multi-factorial. It may cause disturbances in the apoptotic machinery, p-glycoprotein and the multidrug resistance protein family, HER-2/neu gene amplification and protein expression, along with the expression of additional members of the epithelial growth factor receptor family, DNA ploidy, p53 gene mutations, cyclin E and p27 dysregulation that cumulatively drive the development of cancer stem cells [87].

Previous genome-wide association studies have identified a common risk variant at the TERT-CLPTM1L locus on chromosome 5p15 (odds ratio $(\mathrm{OR})=1.25, p=1.1 \times 10^{-9}$ ), which was present at greater frequency in African Americans than in women of European ancestry, and was significantly associated with triple negative breast cancer in younger women (aged $<50$ years; $\mathrm{OR}=1.48, p=1.9 \times 10^{-9}$ ) [7]. A series of scientific reports have linked breast cancer drug resistance to disturbed or over-expression of pro-survival stress genes including Bcl-1, Mcl-1 and other BH3 family members [88]. This is confirmed from the observation that BH3 mimetic ABT-737 can sensitize BH3 protein over-expressing breast cancer cells [89]. Other reports have also linked disturbed proteasome signaling to breast cancer chemo and radio resistance [90]. These findings become particularly relevant as proteasome inhibitor bortezomib treatment causes suppression of MDRs leading to induction of apoptosis in breast tumor models [91]. Recent collaborative studies by our group called "Getting to Know Cancer" have demonstrated that inherent resistant traits of breast cancer are associated with malfunctioning of the apoptosis signaling. Targeting the different pathways that either induce apoptosis or suppress the pro-survival signaling is expected to resulting in overcoming drug resistance to various therapies [92].

\section{Conclusions}

Collectively, this review paper provides considerable evidence that breast cancer mortality rate is significantly high among minority African American women population compared to White women in the United States [93-96]. For instance, a 2013 report indicated that the relative 5 year breast cancers survival rate was 78\% among Black women and 90\% among White women between 2002 and 2008 [97]. This high mortality rate in breast cancer among minorities may be attributed to lack of medical coverage, barriers to early detection and screening, more advanced stage of disease at diagnosis among minorities, and unequal access to improvements in cancer treatment [70-72]. Many African American women have frequent unknown or un-staged breast cancers than White women. These are scientific evidences that may explain the differences in breast cancer treatment and survival rate among African American and White women. With the current scientific knowledge and advance in early detection for breast cancer, there are great possibilities to reduce breast cancer incidence rate in the near future. Although there has been an improvement in early detection, diagnosis, and screening, many Black women are less likely to receive the same level of quality care compared with White women $[20,21]$. Therefore, new strategies and approaches are needed to promote breast cancer prevention, improve survival rate, reduce breast cancer mortality, and ultimately improve the health outcomes of racial/ethnic minorities.

Acknowledgments: This research was supported in part by the National Institutes of Health (NIH) grant \# G12MD007581 through the Research Centers in Minority Institutio (RCMI)-Center for Environmental Health, and in part by the NIH grant \# P20MD006899 through the Center for Minority Health and Health Disparities at Jackson State University. Research reported in this publication was supported by the National Institute on Minority Health and Health Disparities of the National Institutes of Health under Award Number P20MD006899. The content is solely the responsibility of the authors and does not necessarily represent the official views of the National Institutes of Health. 
Author Contributions: Clement G. Yedjou, Paul B. Tchounwou, Marinelle Payton and Duber D. Fonseca conceived, designed, and drafted the manuscript; and Lucio Miele, Leroy Lowe and Richard A. Alo participated in the implementation of the study and acquisition of data. All authors read and approved the final draft of the manuscript.

Conflicts of Interest: The authors declare no conflict of interest.

\section{References}

1. Torre, L.A.; Bray, F.; Siegel, R.L.; Lortet-Tieulent, J.; Jemal, A. Global cancer statistics, 2012. CA Cancer J. Clin. 2015, 65, 87-108. [CrossRef] [PubMed]

2. Surveillance, Epidemiology, and End Results (SEER) Program. SEER ${ }^{*}$ Stata Database: Incidence SEER 18 RegS Research Data + Hurricane Katrina Impacted Louisiana Cases, Nov. 2013 Sub (20002011) <Katrina/Rita Population Adjustment> Linked to County Attributes Total US, 19692012 Counties; National Cancer Institute, Division of Cancer Control and Population Sciences, Surveillance Research Program, Surveillance Systems Branch: Bethesda, MD, USA, 2014.

3. Surveillance, Epidemiology, and End Results (SEER) Program. SEER*Stat Database: Mortality-All COD, Aggregated With State Total US (19692010) <Katrina/Rita Population Adjustment>; National Cancer Institute, Division of Cancer Control and Population Sciences, Surveillance Research Program, Surveillance Systems Branch: Bethesda, MD, USA, 2013.

4. Pinheiro, S.P.; Holmes, M.D.; Pollak, M.N.; Barbieri, R.L.; Hankinson, S.E. Racial differences in premenopausal endogenous hormones. Cancer Epidemiol. Biomark. Prev. 2005, 14, 2147-2153. [CrossRef] [PubMed]

5. Hall, I.J.; Moorman, P.G.; Millikan, R.C.; Newman, B. Comparative analysis of breast cancer risk factors among African-American women and White women. Am. J. Epidemiol. 2005, 161, 40-51. [CrossRef] [PubMed]

6. Chlebowski, R.T.; Chen, Z.; Anderson, G.L.; Rohan, T.; Aragaki, A.; Lane, D.; Dolan, N.C.; Paskett, E.D.; McTiernan, A.; Hubbell, F.A.; et al. Ethnicity and breast cancer: Factors influencing differences in incidence and outcome. J. Natl. Cancer Inst. 2005, 97, 439-448. [CrossRef] [PubMed]

7. Haiman, C.A.; Chen, G.K.; Vachon, C.M.; Canzian, F.; Dunning, A.; Millikan, R.C.; Wang, X.; Ademuyiwa, F.; Ahmed, S.; Ambrosone, C.B.; et al. A common variant at the TERT-CLPTM1L locus is associated with estrogen receptor-negative breast cancer. Nat. Genet. 2011, 43, 1210-1214. [CrossRef] [PubMed]

8. Kato, I.; Cichon, M.; Yee, C.L.; Land, S.; Korczak, J.F. African American-preponderant single nucleotide polymorphisms (SNPs) and risk of breast cancer. Cancer Epidemiol. 2009, 33, 24-30. [CrossRef] [PubMed]

9. Ray, M.; Polite, B.N. Triple-negative breast cancers: A view from 10,000 feet. Cancer J. 2010, 16, 17-22. [CrossRef] [PubMed]

10. Setiawan, V.W.; Monroe, K.R.; Wilkens, L.R.; Kolonel, L.N.; Pike, M.C.; Henderson, B.E. Breast cancer risk factors defined by estrogen and progesterone receptor status: The multiethnic cohort study. Am. J. Epidemiol. 2009, 169, 1251-1259. [CrossRef] [PubMed]

11. Dunnwald, L.K.; Rossing, M.A.; Li, C.I. Hormone receptor status, tumor characteristics, and prognosis: A prospective cohort of breast cancer patients. Breast Cancer Res. 2007, 9, R6. [CrossRef] [PubMed]

12. Porter, P.L.; Lund, M.J.; Lin, M.G.; Yuan, X.; Liff, J.M.; Flagg, E.W.; Coates, R.J.; Eley, J.W. Racial differences in the expression of cell cycle-regulatory proteins in breast carcinoma. Cancer 2004, 100, 2533-2542. [CrossRef] [PubMed]

13. Martin, D.N.; Boersma, B.J.; Yi, M.; Reimers, M.; Howe, T.M.; Yfantis, H.G.; Tsai, Y.C.; Williams, E.H.; Lee, D.H.; Stephens, R.M.; et al. Differences in the tumor microenvironment between African-American and European-American breast cancer patients. PLoS ONE 2009, 4, e4531. [CrossRef] [PubMed]

14. Gukas, I.D.; Girling, A.C.; Mandong, B.M.; Prime, W.; Jennings, B.A.; Leinster, S.J. A comparison of clinicopathological features and molecular markers in British and Nigerian women with breast cancer. Clin. Med. Oncol. 2008, 2, 347-351. [CrossRef]

15. Mehrotra, J.; Ganpat, M.M.; Kanaan, Y.; Fackler, M.J.; McVeigh, M.; Lahti-Domenici, J.; Polyak, K.; Argani, P.; Naab, T.; Garrett, E.; et al. Estrogen receptor/progesterone receptor-negative breast cancers of young African-American women have a higher frequency of methylation of multiple genes than those of Caucasian women. Clin. Cancer Res. 2004, 10, 2052-2057. [CrossRef] [PubMed] 
16. Dookeran, K.A.; Dignam, J.J.; Ferrer, K.; Sekosan, M.; McCaskill-Stevens, W.; Gehlert, S. p53 as a marker of prognosis in African-American women with breast cancer. Ann. Surg. Oncol. 2010, 17, 1398-1405. [CrossRef] [PubMed]

17. Loo, L.W.; Wang, Y.; Flynn, E.M.; Lund, M.J.; Bowles, E.J.; Buist, D.S.; Liff, J.M.; Flagg, E.W.; Coates, R.J.; Eley, J.W.; et al. Genome-wide copy number alterations in subtypes of invasive breast cancers in young white and African American women. Breast Cancer Res. Treat. 2011, 127, 297-308. [CrossRef] [PubMed]

18. Yip, C.H.; Smith, R.A.; Anderson, B.O.; Miller, A.B.; Thomas, D.B.; Ang, E.S.; Caffarella, R.S.; Corbex, M.; Kreps, G.L.; McTiernan, A. Guideline implementation for breast healthcare in low- and middle-income countries: Early detection resource allocation. Cancer 2008, 113, 2244-2256. [CrossRef] [PubMed]

19. Ferlay, J.; Soerjomataram, I.; Dikshit, R.; Eser, S.; Mathers, C.; Rebelo, M.; Parkin, D.M.; Forman, D.; Bray, F. Cancer incidence and mortality worldwide: Sources, methods and major patterns in GLOBOCAN 2012. Int. J. Cancer 2015, 136, E359-E386. [CrossRef] [PubMed]

20. Tammemagi, C.M. Racial/ethnic disparities in breast and gynecologic cancer treatment and outcomes. Curr. Opin. Obstet. Gynecol. 2007, 19, 31-36. [CrossRef] [PubMed]

21. Hirschman, J.; Whitman, S.; Ansell, D. The Black:White disparity in breast cancer mortality: The example of Chicago. Cancer Causes Control 2007, 18, 323-333. [CrossRef] [PubMed]

22. Coleman, M.P.; Quaresma, M.; Berrino, F.; Lutz, J.M.; De Angelis, R.; Capocaccia, R.; Baili, P.; Rachet, B.; Gatta, G.; Hakulinen, T.; et al. Cancer survival in five continents: A worldwide population-based study (CONCORD). Lancet Oncol. 2008, 9, 730-756. [CrossRef]

23. Howlader, N.; Noone, A.M.; Krapch, O.M.; Miller, D.; Bishop, K.; Altekruse, S.F.; Kosary, C.L.; Yu, M.; Ruhl, J.; Tatalovich, Z.; et al. SEER Cancer Statistics Review, 1975-2013; National Cancer Institute: Bethesda, MD, USA, 2016.

24. American Cancer Society. Breast Cancer Facts \& Figures, 2015-2016; American Cancer Society: Atlanta, GA, USA, 2015.

25. American Cancer Society. Cancer Facts and Figures for African Americans 2016-2018; American Cancer Society: Atlanta, GA, USA, 2016.

26. Ademuyiwa, F.O.; Groman, A.; O'Connor, T.; Ambrosone, C.; Watroba, N.; Stephen, B.; Edge, S.B. Impact of body mass index on clinical outcomes in triple negative breast cancer. Cancer 2011, 117, 4132-4140. [CrossRef] [PubMed]

27. American Cancer Society (ACS). Cancer Facts and Figures for African Americans 2011-2012; American Cancer Society: Atlanta, GA, USA, 2011.

28. Gail, M.H.; Costantino, J.P.; Bryant, J.; Croyle, R.; Freedman, L.; Helzlsouer, K.; Vogel, V. Weighing the risks and benefits of Tamoxifen treatment for preventing breast cancer. J. Natl. Cancer Inst. 1999, 91, 1829-1846. [CrossRef] [PubMed]

29. Connor, C.S.; Touijer, A.K.; Krishnan, L.; Mayo, M.S. Local recurrence following breast conservation therapy in African-American women with invasive breast cancer. Am. J. Surg. 2000, 179, 22-26. [CrossRef]

30. American Cancer Society (ACS). African American 2013-2014 Cancer Facts; ACS: Atlanta, GA, USA, 2013.

31. Surveillance, Epidemiology, and End Results (SEER) Program. SEER ${ }^{*}$ Stat Database: North American Association of Central Caner Registries (NAACCR) Incidence-CiNA Analytic File, 1995-2012, Custom File with County, North American Association of Central Cancer Registries; National Cancer Institute, Division of Cancer Control and Population Sciences, Surveillance Research Program, Cancer Statistics Branch: Bethesda, MD, USA, 2015.

32. Parkin, D.M.; Boyd, L.; Walker, L.C. The fraction of cancer attributable to lifestyle and environmental factors in the UK in 2010. Br. J. Cancer 2011, 105, S77-S81. [CrossRef] [PubMed]

33. Howlader, N.; Noone, A.M.; Krapcho Garshell, J.; Miller, D.; Altekruse, S.F.; Kosary, C.L.; Yu, M.; Ruhl, J.; Tatalovich, Z.; Mariotto, A.; et al. SEER Cancer Statistics Review, 1975-2012; Based on November 2014 SEER Data Submission, Posted to the SEER Web Site April 2015; National Cancer Institute: Bethesda, MD, USA, 2015.

34. Hartmann, L.C.; Sellers, T.A.; Frost, M.H.; Frost, M.H.; Lingle, W.L.; Degnim, A.C.; Ghosh, K.; Vierkant, R.A.; Maloney, S.D.; Pankratz, V.S.; et al. Benign breast disease and the risk of breast cancer. N. Engl. J. Med. 2005, 353, 229-237. [CrossRef] [PubMed]

35. Eberl, M.M.; Sunga, A.Y.; Farrell, C.D.; Mahoney, M.C. Patients with a Family History of Cancer: Identification and Management. JABFM 2005, 18, 211-217. [CrossRef] 
36. Campeau, P.M.; Foulkes, W.D.; Tischkowitz, M.D. Hereditary breast cancer: New genetic developments, new therapeutic avenues. Hum. Genet. 2008, 124, 31-42. [CrossRef] [PubMed]

37. Pal, T.; Permuth-Wey, J.; Betts, J.A.; Krischer, J.P.; Fiorica, J.; Arango, H.; LaPolla, J.; Hoffman, M.; Martino, M.A.; Wakeley, K.; et al. BRCA1 and BRCA2 mutations account for a large proportion of ovarian carcinoma cases. Cancer 2005, 104, 2807-2816. [CrossRef] [PubMed]

38. Emedicinehealth. Breast Cancer. Available online: http://www.emedicinehealth.com/breast_cancer/page2 em.htm (accessed on 20 March 2010).

39. Easton, D.F. How many more breast cancer predisposition genes are there? Breast Cancer Res. 1999, 1, 14-17. [CrossRef] [PubMed]

40. Bièche, I.; Lidereau, R. Genetic alterations in breast cancer. Genes Chrom. Cancer 1995, 14, 227-251. [CrossRef] [PubMed]

41. McBride, O.W.; Merry, D.; Givol, D. The gene for human p53 cellular tumor antigen is located on chromosome 17 short arm (17p13). Proc. Natl. Acad. Sci. USA 1986, 83, 130-134. [CrossRef] [PubMed]

42. Miller, C.; Mohandas, T.; Wolf, D.; Prokocimer, M.; Rotter, V.; Koeffler, H.P. Human p53 gene localized to short arm of chromosome 17. Nature 1986, 319, 783-784. [CrossRef] [PubMed]

43. Miki, Y.; Swensen, J.; Shattuck-Eidens, D.; Futreal, P.A.; Harshman, K.; Tavtigian, S.; Liu, Q.; Cochran, C.; Bennett, L.M.; Ding, W.; et al. A strong candidate for the breast and ovarian cancer susceptibility gene BRCA1. Science 1994, 266, 66-71. [CrossRef] [PubMed]

44. Wooster, R.; Bignell, G.; Lancaster, J.; Swift, S.; Seal, S.; Mangion, J.; Collins, N.; Gregory, S.; Gumbs, C.; Micklem, G. Identification of the breast cancer susceptibility gene BRCA2. Nature 1995, 378, 789-792. [CrossRef] [PubMed]

45. Elledge, R.M.; Clark, G.M.; Chamness, G.C.; Osborne, C.K. Tumor biologic factors and breast cancer prognosis among white, Hispanic, and black women in the United States. J. Natl. Cancer Inst. 1994, 86, 705-712. [CrossRef] [PubMed]

46. National Cancer Institute. Genetics of Breast and Gynecologic Cancers (PDQ ${ }^{\circledR}$ )—Health Professional Version. Available online: http://www.cancer.gov/types/breast/hp/breast-ovarian-genetics-pdq\#section/ 88 (accessed on 30 March 2017).

47. Irigaray, P.; Newby, J.A.; Clapp, R.; Hardell, L.; Howard, V.; Montagnier, L.; Epstein, S.; Belpomme, D. Lifestyle-related factors and environmental agents causing cancer: An overview. Biomed. Pharmacother. 2007, 61, 640-658. [CrossRef] [PubMed]

48. Lee, I.; Oguma, Y. Physical activity. In Cancer Epidemiology and Prevention, 3rd ed.; Schottenfeld, D., Fraumeni, J.F., Eds.; Oxford University Press: New York, NY, USA, 2006.

49. McTiernan, A. (Ed.) Cancer Prevention and Management through Exercise and Weight Control; Taylor \& Francis Group, LLC: Boca Raton, FL, USA, 2006.

50. Lynch, B.M.; Neilson, H.K.; Friedenreich, C.M. Physical activity and breast cancer prevention. Recent Results Cancer Res. 2011, 186, 13-42. [PubMed]

51. Albuquerque, R.C.; Baltar, V.T.; Marchioni, D.M. Breast cancer and dietary patterns: A systematic review. Nutr. Rev. 2014, 72, 1-17. [CrossRef] [PubMed]

52. Ferrari, P.; Rinaldi, S.; Jenab, M.; Lukanova, A.; Olsen, A.; Tjønneland, A.; Overvad, K.; Clavel-Chapelon, F.; Fagherazzi, G.; Touillaud, M.; et al. Dietary fiber intake and risk of hormonal receptor-defined breast cancer in the European Prospective Investigation into Cancer and Nutrition study. Am. J. Clin. Nutr. 2013, 97, 344-353. [CrossRef] [PubMed]

53. Deschasaux, M.; Zelek, L.; Pouchieu, C.; His, M.; Hercberg, S.; Galan, P.; Latino-Martel, P.; Touvier, M. Prospective association between dietary fiber intake and breast cancer risk. PLoS ONE 2013, 8, e79718. [CrossRef] [PubMed]

54. Aune, D.; Chan, D.S.; Vieira, A.R.; Rosenblatt, D.A.; Vieira, R.; Greenwood, D.C.; Norat, T. Fruits, vegetables and breast cancer risk: A systematic review and meta-analysis of prospective studies. Breast Cancer Res. Treat. 2012, 134, 479-493. [CrossRef] [PubMed]

55. Fung, T.T.; Chiuve, S.E.; Willett, W.C.; Hankinson, S.E.; Hu, F.B.; Holmes, M.D. Intake of specific fruits and vegetables in relation to risk of estrogen receptor-negative breast cancer among post-menopausal women. Breast Cancer Res. Treat. 2013, 138, 925-930. [CrossRef] [PubMed]

56. Stolley, M.R.; Sharp, L.K.; Wells, A.M.; Simon, N.; Schiffer, L. Health behaviors and breast cancer: Experiences of urban African American women. Health Educ. Behav. 2006, 33, 604-624. [CrossRef] [PubMed] 
57. Ligibel, J. Obesity and Breast Cancer. Oncology 2011, 25, 994-1000. [PubMed]

58. Smith-Warner, S.A.; Spiegelman, D.; Adami, H.O.; Beeson, W.L.; van den Brandt, P.A.; Folsom, A.R.; Fraser, G.E.; Freudenheim, J.L.; Goldbohm, R.A.; Graham, S.; et al. Types of dietary fat and breast cancer: A pooled analysis of cohort studies. Int. J. Cancer 2001, 92,767-774. [CrossRef]

59. Willett, W.C. Diet and cancer. Oncologist 2000, 5, 393-404. [CrossRef] [PubMed]

60. Bowlin, S.J.; Leske, M.C.; Varma, A.; Nasca, P.; Weinstein, A.; Caplan, L. Breast cancer risk and alcohol consumption: Results from a large case-control study. Int. J. Epidemiol. 1997, 26, 915-923. [CrossRef] [PubMed]

61. Ewertz, M. Alcohol consumption and breast cancer risk in Denmark. Cancer Causes Control 1991, 2, $247-252$. [CrossRef] [PubMed]

62. Nagata, C.; Kabuto, M.; Takatsuka, N.; Shimizu, H. Associations of alcohol, height, and reproductive factors with serum hormone concentrations in postmenopausal Japanese women. Steroid hormones in Japanese postmenopausal women. Breast Cancer Res. Treat. 1997, 44, 235-241. [CrossRef] [PubMed]

63. Collaborative Group on Hormonal Factors in Breast Cancer. Alcohol, tobacco and breast cancer-Collaborative reanalysis of individual data from 53 epidemiological studies, including 58,515 women with breast cancer and 95067 women without the disease. Br. J. Cancer 2002, 87, 1234-1245.

64. Connolly, B.S.; Barnett, C.; Vogt, K.N.; Li, T.; Stone, J.; Boyd, N.F. A meta-analysis of published literature on waist-to-hip ratio and risk of breast cancer. Nutr. Cancer 2002, 44, 127-138. [CrossRef] [PubMed]

65. Rose, D.P.; Komninou, D.; Stephenson, G.D. Obesity, adipocytokines, and insulin resistance in breast cancer. Obes. Rev. 2004, 5, 153-165. [CrossRef] [PubMed]

66. Lamon-Fava, S.; Barnett, J.B.; Woods, M.N.; McCormack, C.; McNamara, J.R.; Schaefer, E.J.; Longcope, C.; Rosner, B.; Gorbach, S.L. Differences in serum sex hormone and plasma lipid levels in Caucasian and African-American premenopausal women. J. Clin. Endocrinol. Metab. 2005, 90, 4516-4520. [CrossRef] [PubMed]

67. Sephton, S.E.; Sapolsky, R.M.; Kraemer, H.C.; Spiegel, D. Diurnal cortisol rhythm as a predictor of breast cancer survival. J. Natl. Cancer Inst. 2000, 92, 994-1000. [CrossRef] [PubMed]

68. Centers for Disease Control and Prevention (CDC). Prevalence of regular physical activity among adults-United States, 2001 and 2005. Morb. Mortal. Wkly. Rep. 2007, 56, 1209-1212.

69. Colditz, G.A.; Bohlke, K. Priorities for the primary prevention of breast cancer. CA Cancer J. Clin. 2014, 64, 186-194. [CrossRef] [PubMed]

70. Optenberg, S.A.; Thompson, I.M.; Friedrichs, P.; Wojcik, B.; Stein, C.R.; Kramer, B. Race, treatment, and long-term survival from prostate cancer in an equal-access medical care delivery system. JAMA 1995, 274, 1599-1605. [CrossRef] [PubMed]

71. Eley, J.W.; Hill, H.A.; Chen, V.W.; Austin, D.F.; Wesley, M.N.; Muss, H.B.; Greenberg, R.S.; Coates, R.J.; Correa, P.; Redmond, C.K.; et al. Racial differences in survival from breast cancer: Results of the National Cancer Institute Black/White Cancer Survival Study. J. Natl. Cancer Inst. 1995, 87, 1686-1693. [CrossRef]

72. Carey, L.A.; Perou, C.M.; Livasy, C.A.; Dressler, L.G.; Cowan, D.; Conway, K.; Karaca, G.; Troester, M.A.; Tse, C.K.; Edmiston, S.; et al. Race, breast cancer subtypes, and survival in the Carolina Breast Cancer Study. JAMA 2006, 295, 2492-2502. [CrossRef] [PubMed]

73. Harlan, L.C.; Coates, R.J.; Block, G.; Greenberg, R.S.; Ershow, A.; Forman, M.; Heymsfield, S.D. Estrogen receptor status and dietary intakes in breast cancer patients. Epidemiology 1993, 4, 25-31. [CrossRef] [PubMed]

74. Van Ryn, M.; Burke, J. The effect of patient race and socio-economic status on physician perceptions of patients. Soc. Sci. Med. 2000, 50, 813-828. [CrossRef]

75. Hair, B.Y.; Hayes, S.; Tse, C.K.; Bell, M.B.; Olshan, A.F. Racial differences in physical activity among breast cancer survivors: Implications for breast cancer care. Cancer 2014, 120, 2174-2182. [CrossRef] [PubMed]

76. Thompson, C.L.; Owusu, C.; Nock, N.L.; Li, L.; Berger, N.A. Race, age, and obesity disparities in adult physical activity levels in breast cancer patients and controls. Front. Public Health 2014, 2, 150. [CrossRef] [PubMed]

77. Stout, N.L.; Binkley, J.M.; Schmitz, K.H.; Andrews, K.; Hayes, S.C.; Campbell, K.L.; McNeely, M.L.; Soballe, P.W.; Berger, A.M.; Cheville, A.L.; et al. A prospective surveillance model for rehabilitation for women with breast cancer. Cancer 2012, 118, 2191-2200. [CrossRef] [PubMed]

78. Bauer, J.H.; Hefand, S.L. New tricks of an old molecule: Lifespan regulation by p53. Aging Cell 2006, 5, 437-440. [CrossRef] [PubMed]

79. Gasco, M.; Shami, S.; Crook, T. The p53 pathway in breast cancer. Breast Cancer Res. 2002, 4, 70-76. [CrossRef] [PubMed] 
80. Morris, G.J.; Naidu, S.; Topham, A.K.; Guiles, F.; Xu, Y.; McCue, P.; Schwartz, G.F.; Park, P.K.; Rosenberg, A.L.; Brill, K.; et al. Differences in breast carcinoma characteristics in newly diagnosed African-American and Caucasian patients: A single-institution compilation compared with the National Cancer Institute's Surveillance, Epidemiology, and End Results database. Cancer 2007, 110, 876-884. [CrossRef] [PubMed]

81. Donninger, H.; Vos, M.D.; Clark, G.J. The RASSF1A tumor suppressor. J. Cell Sci. 2007, 120, 3163-3172. [CrossRef] [PubMed]

82. Krop, I.; Parker, M.T.; Bloushtain-Qimron, N.; Porter, D.; Gelman, R.; Sasaki, H.; Maurer, M.; Terry, M.B.; Parsons, R.; Polyak, K. HIN-1, an inhibitor of cell growth, invasion, and AKT activation. Cancer Res. 2005, 65, 9659-9669. [CrossRef] [PubMed]

83. Lund, M.J.; Trivers, K.F.; Porter, P.L.; Coates, R.J.; Leyland-Jones, B.; Brawley, O.W.; Flagg, E.W.; O'Regan, R.M.; Gabram, S.G.; Eley, J.W. Race and triple negative threats to breast cancer survival: A population-based study in Atlanta, GA. Breast Cancer Res. Treat. 2009, 113, 357-370. [CrossRef] [PubMed]

84. Nielsen, N.H.; Arnerlov, C.; Emdin, S.O.; Landberg, G. Cyclin E overexpression, a negative prognostic factor in breast cancer with strong correlation to oestrogen receptor status. Br. J. Cancer 1996, 74, 874-880. [CrossRef] [PubMed]

85. Morton, J.P.; Timpson, P.; Karim, S.A.; Ridgway, R.A.; Athineos, D.; Doyle, B.; Jamieson, N.B.; Oien, K.A.; Lowy, A.M.; Brunton, V.G.; et al. Mutant p53 drives metastasis and overcomes growth arrest/senescence in pancreatic cancer. Proc. Natl. Acad. Sci. USA 2010, 107, 246-251. [CrossRef] [PubMed]

86. Videira, M.; Reis, R.L.; Brito, M.A. Deconstructing breast cancer cell biology and the mechanisms of multidrug resistance. Biochim. Biophys. Acta 2014, 1846, 312-325. [CrossRef] [PubMed]

87. Filipova, A.; Seifrtova, M.; Mokry, J.; Dvorak, J.; Rezacova, M.; Filip, S.; Diaz-Gracia, D. Breast cancer and cancer stem cells: A mini-review. Tumori 2014, 100, 363-369. [PubMed]

88. Booy, E.P.; Henson, E.S.; Gibson, S.B. Epidermal growth factor regulates Mcl-1 expression through the MAPK-Elk-1 signalling pathway contributing to cell survival in breast cancer. Oncogene 2011, 30, 2367-2378. [CrossRef] [PubMed]

89. Oakes, S.R.; Vaillant, F.; Lim, E.; Lee, L.; Breslin, K.; Feleppa, F.; Deb, S.; Ritchie, M.E.; Takano, E.; Ward, T.; et al. Sensitization of BCL-2-expressing breast tumors to chemotherapy by the BH3 mimetic ABT-737. Proc. Natl. Acad. Sci. USA 2012, 109, 2766-2771. [CrossRef] [PubMed]

90. Elfadl, D.; Hodgkinson, V.C.; Long, E.D.; Scaife, L.; Drew, P.J.; Lind, M.J.; Cawkwell, L. A pilot study to investigate the role of the $26 \mathrm{~S}$ proteasome in radiotherapy resistance and loco-regional recurrence following breast conserving therapy for early breast cancer. Breast 2011, 20, 334-337. [CrossRef] [PubMed]

91. Panischeva, L.A.; Kakpakova, E.S.; Rybalkina, E.Y.; Stavrovskaya, A.A. Influence of proteasome inhibitor bortezomib on the expression of multidrug resistance genes and AKT kinase activity. Biochemistry 2011, 76, 1009-1016. [CrossRef] [PubMed]

92. Mohammad, R.M.; Muqbil, I.; Lowe, L.; Yedjou, C.; Hsu, H.Y.; Lin, L.T.; Siegelin, M.D.; Fimognari, C.; Kumar, N.B.; Dou, Q.P.; et al. Broad targeting of resistance to apoptosis in cancer. Semin. Cancer Biol. 2015, 35, S78-S103. [CrossRef] [PubMed]

93. Maskarinec, G.; Sen, C.; Koga, K.; Conroy, S.M. Ethnic differences in breast cancer survival: Status and determinants. Women's Health 2011, 7, 677-687. [CrossRef] [PubMed]

94. Ooi, S.L.; Martinez, M.E.; Li, C.I. Disparities in breast cancer characteristics and outcomes by race/ethnicity. Breast Cancer Res. Treat. 2011, 127, 729-738. [CrossRef] [PubMed]

95. Tannenbaum, S.L.; KoruSengul, T.; Miao, F.; Byrne, M.M. Disparities in survival after female breast cancer diagnosis: A population based study. Cancer Causes Control 2013, 24, 1705-1715. [CrossRef] [PubMed]

96. Wray, C.J.; Phatak, U.R.; Robinson, E.K.; Wiatek, R.L.; Rieber, A.G.; Gonzalez, A.; Ko, T.C.; Kao, L.S. The effect of age related breast cancer survival disparities. Ann. Surg. Oncol. 2013, 20, 2541-2547. [CrossRef] [PubMed]

97. DeSantis, C.; Ma, J.; Bryan, L.; Jemal, A. Breast cancer statistics, 2013. CA Cancer J. Clin. 2014, 64, 52-62. [CrossRef] [PubMed]

(C) 2017 by the authors. Licensee MDPI, Basel, Switzerland. This article is an open access article distributed under the terms and conditions of the Creative Commons Attribution (CC BY) license (http:/ / creativecommons.org/licenses/by/4.0/). 